\title{
DO CZYTELNIKÓW „COLLECTANEA THEOLOGICA”
}

Upływa 25 lat od czasu, gdy w 1990 r. na stronie redakcyjnej „Collectanea Theologica” pojawiło się moje nazwisko jako redaktora naczelnego. Nominacja do tej funkcji dokonała się wcześniej, 1 października 1989 r., a powierzył mi ją ks. prof. Helmut Juros, rektor Akademii Teologii Katolickiej. Ponieważ treść zeszytów przygotowanych do wydania w 1989 r. była w zasadzie gotowa, podobnie jak materiały do opublikowania w dwóch pierwszych zeszytach w 1990 r., uznałem, że przez kilka kolejnych miesięcy na stronie redakcyjnej powinno być nadal umieszczane nazwisko poprzednika - ks. prof. Henryka Bogackiego SJ. Ta decyzja miała również związek z istnieniem cenzury. Wszystkie przygotowane do druku materiały musiały być z dużym wyprzedzeniem przekazywane do Głównego Urzędu Kontroli Publikacji i Widowisk. W 1990 r. cenzura prewencyjna została zniesiona i 3. numer kwartalnika za ów rok, przygotowany w całości pod moją redakcją, był pierwszym, który ukazał się bez cenzury.

Pierwszą reakcją na nominację na redaktora naczelnego było dokładne zapoznanie się z historią renomowanego czasopisma. Powstało w 1920 r. we Lwowie pod nazwą „Przegląd Teologiczny. Kwartalnik naukowy". Postanowiłem odbyć podróż do Lwowa i odnaleźć miejsca związane z pierwszymi redaktorami i autorami „Przeglądu Teologicznego", od 1932 r. opatrzonego tytułem „Collectanea Theologica”. Z ogromnym wzruszeniem odnalazłem je na początku lipca 2001 r., wkrótce po pielgrzymce Jana Pawła II na Ukrainę. Ogromnym przeżyciem była zwłaszcza obecność pod adresem Plac Bernardyński 2, gdzie mieściła się pierwsza siedziba redakcji, a także w historycznym gmachu dawnego Uniwersytetu Jana Kazimierza.

Kwartalnik został założony wkrótce po odzyskaniu niepodległości w celu publikowania wyników badań teologów polskich. W 1924 r. 
stał się organem Polskiego Towarzystwa Teologicznego, w 1932 r. przyjął nazwę „Collectanea Theologica” i do 1939 r. był wydawany we Lwowie. Po II wojnie światowej, gdy sytuacja polityczna uległa radykalnym przeobrażeniom, wydawanie kwartalnika wznowiono w 1949 r. w Warszawie. Od 1955 r. był redagowany przez profesorów utworzonej rok wcześniej Akademii Teologii Katolickiej i był czasopismem ATK, po czym, wraz z utworzeniem w 1999 r. Uniwersytetu Kardynała Stefana Wyszyńskiego, stał się czasopismem wydawanym przez UKSW.

Osobisty jubileusz to doskonała sposobność, by wyrazić największą wdzięczność wobec tych, którzy położyli fundament oraz przez dziesięciolecia wytrwale budowali i umacniali tę cząstkę gmachu teologii polskiej, której na imię „,Collectanea Theologica”. Poprzednikami w funkcji redaktora naczelnego kwartalnika teologów polskich byli wybitni księża profesorowie: Teofil Długosz (1920-1923), Aleksy Klawek (1924-1939), Wincenty Kwiatkowski (1949-1964), Jan Stępień (1966-1969) i Henryk Bogacki SJ (1970-1989). Oprócz przerwy w wydawaniu czasopisma w latach 1940-1948, spowodowanej wojną, utratą Lwowa przez Polskę i przeciwnościami okresu powojennego, kwartalnik nie ukazał się w 1965 r. W kolejnych zeszytach wprowadzono istniejący do dzisiaj dział biuletynów i zwiększono liczbę recenzji. Od 1975 r. rozpoczęto wydawanie zeszytów obcojęzycznych.

Ostatnie ćwierćwiecze istnienia „Collectanea Theologica” obfitowało w wiele niezwykle ważnych wydarzeń: pontyfikat Jana Pawła II (1978-2005), Wielki Jubileusz Roku 2000, pontyfikat Benedykta XVI (2005-2013) i dwa lata pontyfikatu papieża Franciszka, wiele dokumentów i wypowiedzi kościelnych, ustawiczna recepcja nauczania II Soboru Watykańskiego, a także liczne wydarzenia na forum krajowym i międzynarodowym. Znalazły one swój oddźwięk zwłaszcza w treści biuletynów, podczas gdy w artykułach najczęściej podejmowano i rozwijano zagadnienia, których sens i oddziaływanie nie są uwarunkowane doraźnymi okolicznościami.

Interesujące zapewne mogą być pewne informacje statystyczne. W ciągu 25 lat do redakcji napłynęło ponad 800 artykułów w języku polskim i ponad 60 tekstów w tzw. językach kongresowych. 
Na łamach kwartalnika ukazało się ich mniej, bo nie wszystkie zostały przyjęte do druku, o czym decydowały, oczywiście, względy merytoryczne. Artykuły zamieszczone w „Collectanea Theologica” stanowią wiarygodny probierz i odzwierciedlenie aktualnego stanu polskiej teologii, jej poziomu i kierunków zainteresowań. Co się tyczy biuletynów, ich treść ustalają redaktorzy, którym - jako współpracownikom - wyrażam ogromną wdzięczność. Do działu recenzji napłynęło prawie 800 tekstów i niemal wszystkie zostały opublikowane. Najtrudniejsza sytuacja dotyczy wydawania zeszytu obcojęzycznego. Pierwotny zamysł przewidywał jeden zeszyt każdego roku, ale okazało się to niemożliwe. W latach 1990-2015 ukazało się 6 zeszytów obcojęzycznych (1994, 1998, 1999, 2001, 2004, 2007), zaś przyczyna jest prozaiczna: nie było więcej wystarczająco dobrych materiałów.

Od 1993 r. kwartalnik ukazuje się w zmienionej szacie graficznej i z podtytułem „Przegląd Teologiczny”. W ciągu minionego ćwierćwiecza radykalnym zmianom uległ jego cykl produkcyjny. W początkowym okresie materiały, dostarczane w zapisie sporządzonym za pomocą maszyny do pisania, były ręcznie opracowywane i redagowane, po czym przekazywane do składu, wracały do ręcznej korekty, a poprawiane jeszcze raz wracały ponownie do zatwierdzenia i dopiero były oddawane do druku. W połowie lat 90 . zaczęły się upowszechniać techniki komputerowe. Przez pewien czas dawny i nowy sposób uprawiania pracy naukowej współistniały ze sobą, co nastręczało niemało kłopotów i nieporozumień. $Z$ początkiem XXI w. techniki komputerowe ostatecznie się przyjęły i upowszechniły tak bardzo, że całkowicie zaprzestano przyjmowania tekstów napisanych na maszynie. Upłynęło znowu kilka lat i techniki informatyczne poczyniły dalsze ogromne postępy: praktycznie wyszły z użycia dyskietki, a upowszechnił się Internet. Obecnie praca nad nadsyłanymi tekstami wygląda zupełnie inaczej, jest o wiele szybsza i dokładniejsza. Żadne inne pokolenie nie przeszło tak gwałtownej i wielostronnej rewolucji, ale nawet najbardziej rozwinięte techniki wymagają udziału i pracy kompetentnych ludzi. Wyrażam wdzięczność wszystkim osobom, które w tym długim i pełnym gwałtownych przeobrażeń okresie włożyły wkład w systematyczne wydawanie 
kwartalnika teologów polskich. Osobne słowa podziękowania kieruję do mgr Hanny Stompor, która od wielu lat zajmuje się opracowywaniem i korektą tekstów zamieszczanych w „Collectanea Theologica”.

Pierwszy przygotowany w całości przeze mnie zeszyt kwartalnika ukazał się jako nr 3. w lecie 1990 r. i zawierał materiały pierwszego sympozjum teologicznego „Kościół a Żydzi i judaizm”, które w 1989 r. odbyło się w warszawskiej ATK. Nie zabrakło wtedy głosów wyrażających zastrzeżenia i wątpliwości, czy takie otwarcie jest właściwe i potrzebne. W następnych latach miały miejsce kolejne sympozja pod tym samym hasłem - w sumie odbyło się ich 18. Materiały wszystkich ukazały się na łamach „Collectanea Theologica” i stanowią wymowne świadectwo wysiłku podjętego w celu realizacji soborowego postulatu dialogu Kościoła katolickiego z Żydami i judaizmem. Okazało się jednak, że ta inicjatywa wyzwoliła też innego rodzaju sprzeciwy. Pojawiły się ze strony środowisk i osób forsujących odmienny profil relacji z judaizmem i zbliżenia z Żydami, ukierunkowany na problematykę społeczną, kulturalną i polityczną, a stroniący od perspektywy religijnej i uprawiania teologii. Byłoby dobrze, gdyby w przyszłości dokonano solidnej prezentacji i wszechstronnego bilansu relacji Kościoła katolickiego w Polsce z Żydami i judaizmem na przełomie XX i XXI w., biorąc pod uwagę i rzetelnie oceniając znaczący wkład $w$ to dzieło udokumentowany na łamach „Collectanea Theologica”.

Niniejszy zeszyt kwartalnika został w dziale artykułów udostępniony teologom protestanckim. Dzieje się tak w ramach przygotowań do jubileuszu 500-lecia reformacji (1517-2017). Aczkolwiek katolickie spojrzenie na to wydarzenie i jego konsekwencje jest pod wieloma względami odmienne niż protestanckie, taka współpraca stanowi świadectwo ekumenicznego otwarcia i dążenia do jedności wszystkich wyznawców Jezusa Chrystusa.

Ks. prof. Waldemar Chrostowski Redaktor naczelny ,Collectanea Theologica” 